\title{
PROMOTING OF SELF-DIRECTED LEARNING IN COOPERATION WITH THE PARENTS FOR CHILDREN IN THE PRESCHOOL AGE
}

\author{
Asja Vanaga \\ Lūcija Rutka \\ Latvijas Universitāte
}

\begin{abstract}
Successful learning process in pre-school requires collaboration between children, educators and parents, whose primary goal is individual understanding of each child to promote his academic performance and personal development as a whole. This paper shows a pre-scientific and theoretical background of self-directed learning in preschool, as well as developed and theoretically substantiated child initiative research method "New friend". Particular attention is given to the promotion of the child's initiative, which is crucial in the process of self-directed learning. The empirical study of children's initiatives shows analysis of collaboration with the parents. A qualitative study reveals pre-school children's initiative promotion opportunities in collaboration with parents, by using research method "New friend".
\end{abstract}

Keywords: Self-directed learning, initiative, educator and family collaboration

\section{Introduction}

In various life situations preschoolers demonstrate the desire to act independently, and to clearly express „I can do that”. A child instinctively searches for answers to own questions, explores, discovers and tries to understand the things he comes into contact. When we read literature for new parents and preschool educators, we can found explanation "window of opportunity". In terms of education, it means period of time, when a child's perception is most effective in all aspects, including cognitive processes. Competent educator can help a child and his family in this period, promoting a child's natural initiative. Child's ability to perceive and learn all the different information defines certain responsibility from family and educators who should regulate the quantity of information, content, and to switch child's initiative to knowledge acquisition activities as much as possible.

The Latvian preschool educational guidance (Regulations No. 533) contains the most important skills, knowledge and evaluation criteria, which is formed according to the specific age, but the pedagogical practice shows that children are not always ready to engage in a carefully planned lessons, so the lessons not giving the desired result.

The article presents scientifically theoretical grounds of Self-directed learning. The main driving force of the children's Self-directed learning is initiative, which is possible to contribute in preschool learning activities and of course in family. Continuous initiative promoting is most important. Preschool learning activities should seamlessly continue at home and being reflected throughout the learning process, regardless the particular environment. 
The article aims to explore the possibilities of promoting self-directed learning in cooperation with the parents for children in the preschool age

Question of research: How to contribute the preschool age child self-directed learning in collaboration with the parents?

\section{Methods of research:}

1. Literary analysis.

2. Projective play in family „New friend”.

3. Notes from parents.

Research base consists of 25 children aged from 6 to 7 years from the educational institution in Riga and 50 parents.

Type of research: qualitative.

\section{Procedure of the research:}

In order to make a research of Self-directed learning promotion in collaboration with parents, the plan was made. The idea and the rules of projective play were introduced to parents. Parents were asked to make individual notes by filling out the special questionnaire. Final results will be discussed individually between parents of each child and educator.

\section{Theoretical background of Self-directed learning in preschool}

In its broadest meaning, 'self-directed learning' describes a process, in which individuals take the initiative, with or without the help of others, in diagnosing their learning needs, formulating learning goals, identifying human and material resources for learning, choosing and implementing appropriate learning strategies, and evaluating learning outcomes (Knowles, 1975).

Self-directed learning model for preschool is based on the natural initiative, which is formed thanks to the rapid development of self-regulation, already in the first years of life. M. Bronson (2002) speaks on the natural initiative development process as a part of self-regulation development.

Erikson (Eriksons, 1968) explores the creative potential, which is realizing in the process of self-acquisition and finding own "I", therefore children need to play in pre-school age. Initiative develops together with need to be active and to collaborative.

Child's experience is constructed through the playground that he is both a learning and working at the same time, "the initiative is directly related to the acquisition of new skills, as well as the development of competencies" (1985, Dzintere 1984, Craig \& Baucum, 2005:420).

One of the main tasks of self-directed learning is to foster child's ability to perceive change as a chance, and realizing the objectives pursued, to seek a solution with the available resources, as well as to promote skills to control own emotions, to find solutions for unexpected situations. The child's natural initiative is a strong enough force to educators and parents as a helper, for the goal to be achieved. It is important for the child when parents and teachers are glad about the new skills, worried about failure, supporting new ideas and 
activities as well (Rutka, 2012). In this way children forms own self-directed behavior model. Children can learn new behavior models, but the learning speed will be individually different as it affects the human personality as a whole. We are not speaking about simple response and remembrance of new information. Learning behavior is a complex process of learning, involving the cognitive processes (perception, attention, memory, thinking, etc.), motivation and physiological characteristics. Learning behavioral models can be affected by several factors (Cloninger, 2013):

1. Attention process - observing model behavior.

2. Model-specific characteristics, the degree of complexity, etc.

3. Process of monitoring-sensor capability, excitement, motivation, perception, etc.

4. The saving process-remembrance of behavior, the symbolic coding, cognitive organization, symbolic trying.

5. Imitation of motion-physical ability, reactions, observation of self-imitation, feedback on accuracy and imitation.

6. Motivational processes-activities for the recognition of valuable enough to be executed, an external amplification, internal reinforcement.

One of the core tasks for parents and educator is to follow if educational methods not create to child anxiety and guilt, because in preschool age child's complex social world initiative can serve both an assistant to become successful and gaining confidence in own forces, as well as becoming a failure and guilt cause. The promotion of the child's initiative is related to the child's determination to explore the world, learning new skills in communication with peers, as well as looking for support from older people in the process of learning social skills (Craig \& Baucum, 2005:381). It is important not to do everything by themselves, but to be with child, to help him physically and mentally, to express interest and delight. In this way the external reinforcement helps to develop internal reinforcement and by the time child starting to enjoy his success, having fun of autonomy to perform various duties independently (Rutka, 2012:124-129). In such situations the adult support may take the form of interest, active collaboration, asking questions, providing feedback. The empirical study is carried out by organizing play with "New friend", where parents together $\mathrm{h}$ children are participating in activities that encourage and observe the child, and later parents make notes in their observations and evaluations sheets.

\section{Theoretical justification of projective game „New friend"}

To promote initiative in self-directed learning process a variety of tasks was created and selected. One of them is projective game "New friend". The theoretical justification of the chosen methods is based on D. Dzintere (Dzintere, 1985) that preschool age child trademark activity consists in the playground, 
which is one of the major children's research methods by observing and making notes on what's happening while playing. D. Dzintere (Dzintere,1997) highlights the playground, which promotes the positive development of children, encourage their autonomy, initiative, curiosity, as well as to express their views, to analyze and conclude, therefore the successful implementation of the preschool guidelines is not possible without the cooperation of the educators and parents.

R.Kaņepēja and Z.Gaugere (Kaņepēja 7 Gaugure, 2012) explaining the concept of cooperation in the common view, which is in the process of experience, exchange of spiritual values that are important to children's comprehensive development, "family and educational collaborative content is the pedagogical objectives of the process and the required elements, which is interpreted and understood both the educational institution and the family" (Kañepēja \& Gaugure, 2012:255).

Positive attitude from educators is significant for the child, encouraging creativity, the ability to understand oneself and reaching the results of its work to raise their self-esteem, but to emphasize trust feedback, equally important in this process are family, peers and their attitude.

During creation of projective game "New friend" and its operational processes, attention was devoted to the subject of the direction recommended daily exercise topics, offering incentives for start-up issues and children's issues are estimated. Projective game "New friend" is based on a toy that a child must be made by himself, as he wishes to see it, not regulating children's fantasies, meanwhile thinking about its durability within next couple of weeks. "New friend" is created as an assistant for communication in various topics of everyday activities, intended both as child and parent to trigger conversations about actual everyday events, developments and opportunities to design future visions.

"New friend" who is looking for his place in the family is like a prompter for a child and parents to escalate intimacy between the moments that have caused positive emotions, starting own family tree research, promoting confidence in children through a sense of their place and importance in the family, as well as to explore the environment and world vision, together with family and love ones.

\section{The empirical study of promoting self-directed learning for 6-7 years old children}

The empirical part is made of self-directed learning research in cooperation with the parents. A study carried out in one of Riga's preschool educational institutions using the projective game "New friend" whose main goal was to promote children's initiative to encourage children to participate actively, to be creative and involve the parents. 
To understand children's readiness for the planned activity, before projective game "New friend" started, it was performed in individual negotiations with each child, and results was fixed according to the set of criteria (statements) regarding the initiative, pointing to a child's activity, and willingness to cooperate, to participate, as well as interest in the environment:

1. I like when other people run games.

2. I like when I run games.

3. I like to start new things.

4. I like to learn new things.

Some of the answers given by children in a discussion were as follows:

Statement Nr.1 - "When others do it I get tired of it", "others just runs and does not put me off", "I like when others run certain games "," do not like that, because the others never even allows me to run the game",

Statement Nr.2 - ,I like to run the game”, ,I like to introduce new rules, and to present it to others. It is interesting",

Statement Nr.3 - ,I like it very much”, ,I like it best of all”,

Statement Nr.4 - „I like new things, then I forget old ones faster”, „I like to learn new things about the sun, space and jellyfish", I don't like so much to learn about the things of the world".

Total group score averages according to the above criteria and on the basis of the responses of children indicate that children's desire to make activities reaches $93 \%$ level, to learn new things around $95 \%$, to play when other rule the process $83 \%$, and to do everything by themselves at $90 \%$.

While proposing different types of children's activities, parents had to record the reactions of children in specially prepared observation sheets, for example, one of the planned activities together with children is to make a toy, which will be named later, and celebrated its birthday. Parents made notes based on their observations both free form, or based on certain criteria:

- At start-up it was necessary to encourage my child.

- Child enthusiastically engaged in the process.

- Child involved others into the process.

- This exercise was interesting for my child.

- This exercise was interesting for me.

Every day parents received the next day's exercise and recommendations from the teacher containing start-up ideas and possible children's issues, as well as the general recommendations of the successful progress of the game. For example, the topic "first dinner with new friend" followed by possible start-up issues. How you friend feels today, on what are on the dinner this evening? What could we cook together today? Who will read the recipe and who will cook?

After the first week, summarizing the earlier observation diaries obtained the following results: the first 2 days, 20 of the 25 children eagerly participated in the process involving family too, but starting from third day activity declined stating that the child's interest and the interest of parents in exercise content is 
decreased. Until the end of the first week 15 families took all exercises. Some parents tried to explain the reasons of not continuing the game as follows:

"Could not involve my child", "child was tired", "this activity did not seem interesting to my child," "I'm not excited on these exercises, originally looked at with skepticism, now my child think the same", as well as phrases that pointed to an interest to continue the promotion of the child's initiative, using the projective game "New friend" in the framework of exercises:

"My child's activity was a surprise," "child is excited about the new game and discusses his skills, talents," "exercises prompted me to talk with child about things that otherwise may not do", "the child's responses and thought process was a positive surprise."

Looking at the above parents ratings and comparing them with their children, the answers given are able to explain the overall treatment to the exercises. For example, under the statement "I like it when the game is run by another" Ieva replies that she does not like it. When looking at the questionnaire that mother filled out, there is a clear trend that the child does not like when mother rules the game, and after a game led the third day interest is lost. All three mentioned questionnaires from parents indicate that the child had a significant impact from parents on their decisions regarding the exercises.

Comparing responses from Jānis with the parent's entries in the diary is a noticeable need for incentives that match the child's statement of "I like it when other people run games".

Peter's parents refused to participate in the activities. According to the observation made by the mother, it was concluded that the child was not interested in the process. The mother's position is contrary to the child's answers that points to a great interest in learning new things, as well as loved when the others rule the game. This example shows how strongly parent's attitude can impact in the promotion of child's initiative.

Compiling notes and information from parents, in most cases fathers and mothers have similar vision on the process, as well as based on the notes it is possible to judge on the process of making "new friend" when the children involved the entire family.

In the first days of game "New friend" the children's activity and interest in the group was not noticeable, as well as conversations between the children of the "new friend" was not much. Educator prompted to speak about "friends" game, encouraged children to make creative works together to bring them home to display to "friend". Activity increased a lot. In the evening the kids went home and told parents that this work (Kaleidoscope, masks, drawings) should be shown to "friend", as well as everything is discussed together with the parents, who are part of the everyday task. Even more activities and own written stories first appeared at the end of the week, when the group discovered the secret of the educator, who also has a new "friend" to show. 
While discussing the progress of the game with the parents at the end of the first week, the parents found out that children are playing with the self-made toy much more that with old ones, bought in stores. Activating "New friend" theme in group has generated a lot of positive emotions and stimulated new ideas for children games both at home and in pre-school. Total interest over the learning activities has grown. Discovering successful storytellers, artists, as well as children better sees their good qualities and ability to recognize their failures as well as the fact that sometimes they are being "just lazy and prefer to do nothing".

\section{Conclusion and discussion}

Preschool age children typically heightens emotions and expression of feelings, so one of the positive cooperation of the child with parents and educators have a mutual empathy and emotional stability, which gives the child a sense of security and trust, enhancing the natural development of the initiative and active participation in the activities of various kinds of creative processes.

Analyzing the results of promoting children's initiative, as well as notes made by parents, it can be concluded that the promotion of the child's initiative is not only dependent on parental skills, interest, but also on the parental interest, pointing to a further study of the issues raised, which will facilitate the creation of a collaborative model of self-directed learning in preschool.

Conducting individual interviews with each child, they became interested during the discussions. Children expressed their thoughts, assumptions and conclusions, reflections, however some of the statements shows interesting trend. There is only $7 \%$ difference in answers to statements "I like when other people run playground" and "I like when I run it" ( $83 \%$ of children likes when others run the game and $90 \%$ would like to do it by themselves).

Looking at the information provided both children and parents it is possible to make the following assumptions:

If the child has expressed a desire that the other people rules in the playground, probably he has delayed in the process of expressing the level of initiative, which may be a positive aspect of the rapid changes in the social environment, but as a negative aspect within this environment, child might be unable to motivate himself for the next operation, further positive emotional growth and natural initiative is hampered by insufficient desire from parents to encourage independent action, stopping at the first setback, accepting it as a normal result, and concluding "it is not interesting for my child". Therefore, the results obtained during the negotiation and following assumption requires further observing, not only the mentioned above, but to make the situation researched and analyzed more in depth. 
Proceeding of the International Scientifical Conference May $23^{\text {th }}-24^{\text {th }}, 2014$

Volume I

\section{Bibliography}

1. Bronson, M. (2002). Self-regulation in Early Childhood: Nature and Nurture. New York: Guilford Publications.

2. Cloninger, S. (2013). Theories of personality: understanding persons. Boston: Pearson.

3. Dzintere, D. (1984). Rotaļa un darbs bērnudārzā. Rīga: Zvaigzne.

4. Dzintere, D., \& Boša, R. (1997). Rotalsspēles. Rīga: Mācību apgāds MT.

5. Eriksons, E. (1998). Identitāte: Jaunība un krīze. Rīga: Jumava.

6. Kaṇepēja, R., Lieǵeniece, D., Mangule, I., Ukstiṇa, R., Dzintere, D., Stangaine, I., u.c. (2012). Ceļā uz skolu. Rīga: Zvaigzne .

7. Knowles, M. S. (1975). Self-directed learning: A guide for learners and teachers. Cambridge: Prentice Hall.

8. Noteikumi par valsts pirmsskolas izglītības vadlīnijām. (2012, 7 31). Retrieved 228 , 2014, from www.Likumi.lv: http://likumi.lv/doc.php?id=250854

9. Rutka, L. (2012). Pedagoga psihologiskā kompetence. Rīga: RaKa.

10. Vorobjovs, A. (2000). Vispārīgā psihologija (Sēj. 212 lpp). Rīga.

11. Крайг, Г., \& Бокум, Д. (2005). Психология развития. Санкт-Петербург: Питер.

Asja Vanaga

Lūcija Rutka
Faculty of Education, Psychology and Art, University of

Latvia

asjavanaga@inbox.lv

+37129113411

Faculty of Education, Psychology and Art, University of Latvia

lucija.rutka@lu.lv 